\title{
Effectiveness of Private Vocational School Lesson Learning In Pandemic Covid-19
}

\author{
Deddy Whinata Kardiyanto ${ }^{1}$, Andri Asrul Setiyawan ${ }^{2}$ \\ \{Deddywhinata@staff.uns.ac.id ${ }^{1}$, andriasrul.ior05@student.uns.ac.id $\left.{ }^{2}\right\}$ \\ Faculty of Sports, Sebelas Maret University, Surakarta, Indonesia ${ }^{1,2}$
}

\begin{abstract}
This study to determine the effectiveness of online learning PJOK subjects in Covid-19 pandemic. The descriptive qualitative was used. A questionnaire and validity used source triangulation. The results are: the factor of planning and making teacher learning materials is effective at 22.5, effective students are 22.5 and parents are quite effective at 17.26; the material delivery factor according to the teacher is classified as effective at 23.5, students are classified as quite effective at 19.05 , and the parents are classified as quite effective at 18.53; the interactivity factor of learning from the teacher's point of view is classified as very ineffective at 6.5 , students are very ineffective at 5.23 , while parents are very ineffective at 5.03; the learning evaluation factor according to the teacher's view is quite effective at 18.5, students are quite effective at 16.34 and parents are quite effective at 16.34. The concluded was online PJOK was a quite effective.
\end{abstract}

Keywords: effectiveness of online learning, COVID-19 pandemic.

\section{Introduction}

The implementation of education with the intention of one of them is to increase quality human resources (HR), for the advancement of the Indonesian nation and state. The basis and objectives of education are fundamental problems in the implementation of education, because the basis of education will determine the style and content of education. The function of education is to prepare for the future so that it is far more prosperous both as individuals and collectively as citizens both nationally and between nations. Sports and Health Physical Education (PJOK) has an important role in the development of student behavior. Sports and health physical education is an educational process aimed at achieving educational goals through physical movement.

However, the Covid-19 pandemic at this time has an impact on all aspects of life including aspects of education from elementary school to college. The existence of this virus outbreak hampers teaching and learning activities that usually take place face-to-face, the Covid-19 pandemic forces a policy of maintaining distance (physical distancing)to minimize the spread of the virus. With the Covid-19 outbreak, teaching and learning activities in Indonesia were replaced from offline learning methods (face-to-face) to online (online) to slow down the rate of spread of the virus. Teachers and students are not face to face but occur remotely which allows teachers and students to be in different places. The government's decision to dismiss students, move the teaching and learning process at schools to be at home.

In general, online learning systems are implemented through computers or laptops and smartphone (HP) connected to an internet connection. Teachers are expected to be able to learn 
together at the same time using groups on social media such as WhatsApp (WA), Google Form, Google Classroom, Gogle Meet, Telegram, Instagram, Zoom or other media as learning media.

In a positive light, this learning is very helpful for the continuity of learning in this pandemic. However, changes in patterns or habits that are very fast and unexpected are very difficult to carry out and are normal when they occur. This significantly changed habits, for example, first, teachers and participants rely heavily on computer devices and internet connections, both teachers and students must be able to change styles, strategies or teaching and learning methods, the third teacher and students must be able to change their communication styles during online learning. this.

Based on the background of the problem above, the problem in this study can be formulated as follows: Can online learning in PJOK subjects be implemented effectively in the Covid 19 era?

\section{Theory study}

The word effectiveness comes from the English language, namely effective, which means successful, precise or achieving the desired target. According to the Big Indonesian Dictionary (KBBI), the definition of effectiveness is something that has an effect or result, is effective, brings results, and is the success of an effort or action. The way to measure effectiveness is to determine the transferbility (ability to move) the principles studied. If the goals can be achieved in a shorter time with a particular strategy than with other strategies, then that strategy is used efficiently.

In learning, careful planning is needed, making learning tools, choosing strategies, media, techniques, learning models, and evaluating learning, all of which are mutually sustainable. It is necessary to use effective and innovative learning models so that learning can be more varied and run smoothly. The use of the learning model is also adjusted to the material to be taught so that the suitability between the two and all components becomes appropriate.

Measuring the effectiveness of learning must always be linked to the achievement of learning objectives. The effectiveness of learning is a measure of the success of an interaction process between students and between students and teachers in educational situations to achieve learning objectives. The effectiveness of learning can be seen from the activities of students during learning, students' responses to learning and mastery of concepts. To achieve an effective and efficient learning concept, it is necessary to have a reciprocal relationship between students and teachers to achieve a common goal, besides that it must also be adapted to the conditions of the school environment, facilities and infrastructure, as well as the learning media needed to help achieve all aspects the development of students.

John Carrol in his book entitled "A Model of School Learning", states that Instructional Effectiveness depends on five factors: 1) Attitude; 2) Ability to Understand Instruction; 3) Perseverance; 4) Opportunuty; 5) Quality of Instruction [1]. Knowing some of these indicators shows that learning can run effectively if there is an attitude and willingness in the child to learn, the readiness of students and teachers in learning activities, and the quality of the material presented. Online learning is an extension of learning in a network (online) with learning patterns through the help of internet networks so that there will be interactions in teaching and learning activities between students and teachers.

The concept of online learning is a learning system that is carried out not face to face, but using a platform that can help the teaching and learning process carried out even though it is far 
away [9]. The purpose of online learning is to provide quality learning services in a network that is massive and open to reach more and wider learning space enthusiasts. Another opinion from E-learning is an asynchronous learning activity through electronic computer devices connected to the internet, where learning participants seek to obtain learning materials that suit their needs [3].

Learning planning is basically a description of some of the activities and actions that will be carried out during the learning process. Thus it can be concluded that the e-learning-based learning planning application contains plans, estimates and an overview of learning activities by utilizing computer networks, both internet and intranet. The scope of learning planning includes four main components, namely objectives, teaching materials or materials, teaching and learning activities, and evaluation.

Learning with e-learning is learning by utilizing internet technology to improve a learning environment with rich content with a wide range of coverage. E-learning is the use of learning media using the internet, to send a series of solutions that can increase knowledge and skills. A statement that reads " in the learning and performance architecture is e-learning not e-learning as it is tradicionally practiced but a broader. E-learning is the use of internet technologies to crate and deliver a rich broad array of instruction resources and solutions, the goal of which is to enhance individual and organizational performance" [8].

Learning evaluation is an indicator tool for assessing the achievement of predetermined goals and assessing the overall teaching implementation process. Evaluation is not just assessing an activity spontaneously and incidentally, but is an activity to assess something in a planned, systematic, and directed manner based on clear objectives [11].

Evaluation activities for the implementation of e-learning learning can be seen in terms of increasing knowledge and skills of the learning environment, and their effects. Evaluation of elearning implementation is a process of analyzing the quality of the web learning process (elearning) and the extent to which the achievement of the e-learning process can be felt by learners. The evaluation is carried out as a form of assessment of the various components contained in e-learning.

PJOK is a very important subject for students to learn today because with knowledge of health and sports practices students can fortify one of them by increasing body resistance (immunity) to prevent the Covid-19 virus. However, the outbreak of pandemic cases since March 2020 until now requires all teaching and learning activities for students to be temporarily carried out at home, this is done to minimize mass physical contact so that it can break the chain of spreading the virus. The government takes a learning policy to be carried out through distance learning with online media (in a network) using either a cellphone, PC, or laptop.

Based on this, it is necessary to have strategies and learning models from good PJOK teachers to be applied to students to improve their competence. Learning strategies and models are a way that teachers use to achieve active and efficient teaching and learning activities. Moreover, the result of the Covid-19 pandemic that hit so that PJOK learning did not run optimally because they had to stay at home and apply physical distancing. So that distance learning / online with its learning pattern through the help of internet networks is applied to PJOK learning so that there will be an interaction of teaching and learning activities between students and teachers and is one of the solutions for teachers in delivering learning material. 


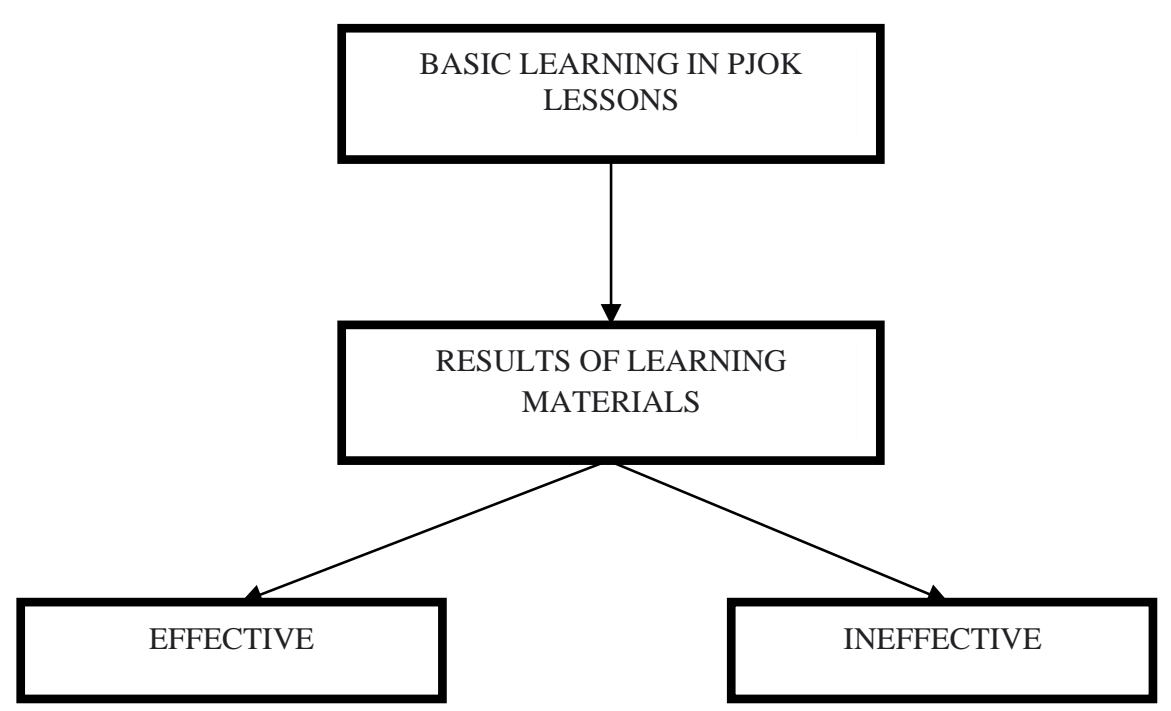

Fig. 1. Research Framework

\section{Research methods}

The research method used by researchers in this study is a qualitative research method. "Qualitative research is a problem-solving strategy in research without using statistical analysis, but by using a logical way of thinking based on qualitative data collected through observation or in-depth interviews with research objects or subjects"[5].

The approach used in this research is a descriptive approach. The analytical descriptive approach is an approach aimed at investigating human activities and work in detail with the aim of providing input for future needs [10]. This study aims to find a detailed and comprehensive picture of the effectiveness of online learning in PJOK subjects. In this study, researchers sought information through giving questionnaires to informants.

The data collection technique used by researchers is nonprobability sampling. In collecting data, this research uses source or data triangulation techniques. Researchers chose informants for class IX SMP Negeri 2 Pemalang, so that the data obtained could represent the effectiveness of online learning in PJOK subjects.

\section{Discussion}

\subsection{Planning and making learning materials (factor 1)}

The items used to track this indicator are questions number 1 to 6 . The results that are tracked are planning and making learning materials. The results of the answers to the questions on planning and making learning materials are presented in table form as follows: 
Table 1. Responses on Planning and Making Learning Materials

\begin{tabular}{ccccccccc}
\hline Sample & \multicolumn{9}{c}{ Data Tabulation } & amou \\
& \multicolumn{9}{c}{ Score Item } & $\begin{array}{c}\text { Avera } \\
\text { ge }\end{array}$ \\
\cline { 2 - 9 } & 1 & 2 & 3 & 4 & 5 & 6 & & \\
Teacher & 8 & 8 & 8 & 6 & 7 & 8 & 45 & 22.5 \\
Student & 939 & 899 & 778 & 743 & 700 & 675 & 4734 & 16.90 \\
Parents & 921 & 906 & 798 & 783 & 721 & 705 & 4834 & 17.26 \\
\hline
\end{tabular}

\subsection{Delivery of Material (factor 2)}

The items used to track this indicator are questions number 7 to 13 . The result that the items tracked is the delivery of e-learning material. The results of the answers to the questions regarding the delivery of e-learning material are presented in table form as follows:

Table 2. Responses on Delivery of Material

\begin{tabular}{|c|c|c|c|c|c|c|c|c|}
\hline \multirow[t]{3}{*}{ Sample } & \multicolumn{8}{|c|}{ Data Tabulation } \\
\hline & \multicolumn{6}{|c|}{ Item Question } & \multirow{2}{*}{ amount } & \multirow{2}{*}{ Average } \\
\hline & 7 & 8 & 9 & 10 & 11 & 12 & & \\
\hline Teacher & 6 & 6 & 8 & 8 & 7 & 7 & 5 & 23.5 \\
\hline Student & 911 & 814 & 618 & 662 & 927 & 680 & 733 & 19.05 \\
\hline Parents & 858 & 792 & 604 & 662 & 861 & 692 & 720 & 18.53 \\
\hline
\end{tabular}

\subsection{Learning Interactivity (factor 3)}

The items used to track this indicator are questions number 7 to 13 . The results that the items tracked are e-learning interactions. The results of the answers to the e-learning learning interaction questions are presented in table form as follows:

Table 3. Responses on Learning Interactivity

\begin{tabular}{ccccc}
\hline Sample & \multicolumn{4}{c}{ Data Tabulation } \\
& \multicolumn{2}{c}{ Item Questions } & amount & Average \\
\cline { 2 - 3 } Teacher & 14 & 15 & & 6.5 \\
Student & 7 & 6 & 13 & 5.23 \\
Parents & 719 & 746 & 1465 & 5.03 \\
\hline
\end{tabular}

\subsection{Learning Evaluation (factor 4)}

The items used to track this indicator are questions number 16 to 21 . The result that the items tracked is the evaluation of e-learning learning. The results of the answers to the evaluation questions on e-learning are presented in table form as follows: 
Table 4. Responses on Learning Evaluation

\begin{tabular}{|c|c|c|c|c|c|c|c|c|}
\hline \multirow[t]{3}{*}{ Sample } & \multicolumn{8}{|c|}{ Data Tabulation } \\
\hline & \multicolumn{6}{|c|}{ Score Item } & \multirow{2}{*}{ amount } & \multirow{2}{*}{ Average } \\
\hline & 16 & 17 & 18 & 19 & 20 & 21 & & \\
\hline Teacher & 8 & 6 & 4 & 5 & 6 & 8 & 37 & 18.5 \\
\hline Student & 684 & 705 & 793 & 697 & 923 & 774 & 4576 & 16.34 \\
\hline Parents & 686 & 674 & 851 & 722 & 898 & 745 & 4576 & 16.34 \\
\hline
\end{tabular}

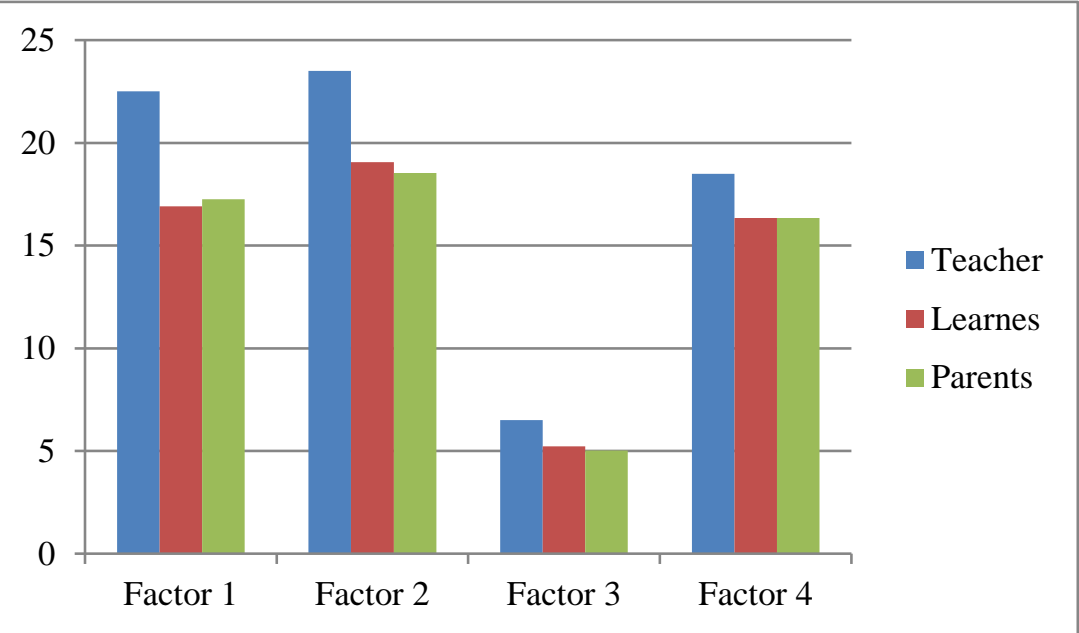

Fig. 2. Response Bar Chart for Teachers, Students, and Parents

Based on the results of the responses from teachers, students, and parents regarding several factors of the effectiveness of online learning in PJOK, it is known that the first factor is the teacher's average of 22.5, students 16.90, parents 17.26. The second factor was obtained by an average of 23.5 from teachers, students 19.05 , parents 18.53 . The third factor was obtained by an average of 6.5 teachers, 5.23 students, 5.03 parents. And the fourth factor obtained an average of 18.5 from teachers, 16.34 students, and 16.34 parents.

Table. 5. Rating Category Table

\begin{tabular}{ccc}
\hline No. & Interval & Category \\
\hline 1 & $6-10.5$ & Very Ineffective \\
2 & $10.6-15.1$ & Ineffective \\
3 & $15.2-19.7$ & Effective enough \\
4 & $19.8-24$ & Effective \\
\hline
\end{tabular}

From the results of the research that has been carried out, the results obtained data on the effectiveness of online learning in PJOK subjects in class IX students at SMP Negeri 2 Pemalang in the academic year 2020/2021. From the data obtained about several factors on the effectiveness of online learning in the PJOK subject, it shows a different average from the respondents of teachers, students, and parents, namely as follows:

Planning and Making Learning Materials 
Based on the results of data analysis about the factors of planning and making learning materials according to the PJOK teacher, it has an average of 22.5 with the Effective category, according to the students having an average of 16.90 which is quite effective, while the parents have an average of 17,26 which is classified as Moderately Effective.

Delivery of Material

Based on the results of data analysis about the delivery factors of online material in PJOK subjects using the google meet application, according to the PJOK teacher, it has an average of 23.5 with an Effective category, according to the students having an average of 19.05 which is classified as Quite Effective, parents have an average of 18.53 which is classified as Enough Effective.

Learning Interactivity

Based on the results of data analysis about the factors of online learning in PJOK subjects using the google meet application, according to the PJOK teacher, it has an average of 6.5 with the Very Ineffective category, according to the students having an average of 5.23 which is classified as Very Ineffective, while the parents have an average of 5.03 which is classified as Very Ineffective. When the teacher will divide the group for discussion of the material that will be given it will be difficult to do because the facial appearance of the students cannot be used as one screen, so it is also difficult to interact and discuss the students in one group and the teacher who cannot directly supervise whether the students are all Students are active or not, especially if the internet is slow according to the opinion of Sawitri D.

Learning Evaluation

Based on the results of data analysis on the evaluation factors of online learning in PJOK, according to the PJOK teachers, it has an average of 18.5 with the Fairly Effective category, according to the students having an average of 16.34 which is classified as quite effective, while the parents have an average of 16.34. average 16.34 which is classified as Moderately Effective.

\section{Conclusion}

From the results of the analysis and discussion in chapter IV on the effectiveness of online learning in PJOK subjects, the results are quite effective as a whole, but also still require increased mastery of certain indicators that exist in the aspect of effectiveness of online learning. In planning and making learning material factors according to the teacher is classified as effective with an average of 22.5, while according to students it is classified as quite effective with an average of 16.90, and parents are classified as quite effective with an average of 17.26. The material delivery factor according to the opinion of the teacher was classified as effective with an average of 23.5, while the students' opinion was classified as quite effective at 19.05, and the parents were classified as quite effective with an average of 18.53. The learning interactivity factor from the teacher's point of view is classified as very ineffective with an average of 6.5, according to the students it is classified as very ineffective with an average of 5.23 , while parents are also classified as very ineffective with an average of 5.03 . And the learning evaluation factor according to the view of the teacher is classified as quite effective with an average of 18.5 , according to students it is classified as quite effective with an average of 16.34 and according to parents is also quite effective with an average of 16.34 .

Based on the description above, it can be concluded that learning about PJOK through the Covid pandemic in 2020/2021 was quite effective. 


\section{References}

[1] Afifatu, R. (2015). Learning Effectiveness: Journal of Early Childhood Education Volume 9, Issue 1 (page: 16). Jakarta: UNJ.https: //doi.org/10.21009/JPUD.091

[2] Arsyad, A. (2011). Learning Media. Jakarta: Raja Grafindo Persada.

[3] Aunurrahman. (2014). Learning and Learning. Bandung: Alfabeta.

[4] Generous, Deni. (2013). Quantitative Research Methods.Bandung: PT Remaja Rosdakarya.)

[5] Don Morrison. (2003). E-learning Strategies (How to Get Implementation And Delivery Rigth First Time). England: British Library.

[6] Ega, RW (2016). Variety of Learning Media Visual-Audio Visual-Computer-Power Point-InternetInteractive Video. Publisher: Kata Pena.

[7] Muhammad Darwis, D. \& Aprida P. (2017). Learning and Learning. Journal of Islamic Studies (Vol. 03 No. 2 December 2017). Padang Sidimpuan: IAIN. Web journal.iainpadangsidimpuan.ac.id/index.php/F.

[8] Numiek, SH (2013). The effectiveness of E-learning as a Learning Media (Evaluation Study of Elearning Learning Model) SMK Telkom Sandhy Putra PurwokertoI: Journal of Vocational Education Vol.3 Number 1. UNY Yogyakarta.

[9] Oktafia, IH (2020). Online Learning as a Study From Home (SFH) Effort During the Covid 19 Pandemic: Journal of Office Administration Education (JPAP) Volume 8 (page: 498). Surabaya: Kompasiana.com. https://journal.unesa.ac.id/index.php/jpap

[10] Prawiyogi, AG, Purwanugraha, A., Fakhry, G., Firmansyah, M. (2020). The Effectiveness of Distance Learning on the Learning of Students at SDIT Cendekia Purwakarta. Journal of Basic Education. (pp. 95-96) Doi.org/10.21009/JPD.011.10

[11] Roman AP, Paulus IS \& Eko N. (2019). Factors Affecting the Success of Online Learning in the Industrial Revolution 4.0. Journal of the National Seminar on Computer Technology \& Science (SAINTEK) (p. 56). Yogyakarta: UNY. https://seminar-id.com/semnas-sainteks2019.html

[12] Sawitri, D. (2020). Use of Google Meet for Work From Home in the Pandemic Era of Coronavirus Disease 2019 (Covid-19): Journal of Community Service Volume 02 (p. 14). Medan: Harapan University Medan. 161-Article Text-563-1-10-20200722.pdf

[13] Supentanginingrum, J. (2013). Theory and Application Learning Strategy. First printing. Yogyakarta: AriRuz Media.

[14] Surahni. (2017). Sports and Health Physical Education (PJOK) as a Means of Moral Education: Journal of Muhammadiyah Magelang University (p. 42). Magelang: Muhammadiyah University of Magelang

[15] Wiarto, G. (2016). Learning Media in Physical Education. Yogyakarta: Laksitas 